УДК 676.024

\title{
ИССЛЕДОВАНИЕ ВЛИЯНИЯ ПОЛИКАТИОНОГЕННЫХ ПОЛИМЕРОВ НА ЭЛЕКТРОКИНЕТИЧЕСКИЕ СВОЙСТВА МАКУЛАТУРНОЙ МАССЫ И МЕХАНИЧЕСКУЮ ПРОЧНОСТЬ ТЕСТ-ЛАЙНЕРА
}

\section{(C) С.Ю. Кожевников}

\author{
Общество с ограниченной ответственностью «СКИФ Спешиал Кемикалз», \\ Восточная промзона, 7, Дзержинск, Нижегородская обл., 606000 (Россия), \\ e-mail: skif@skif.us
}

\begin{abstract}
Исследовано влияние фиксаторов, флоккулянтов и связующего для повышения влагопрочности на электрокинетические свойства макулатурной массы и механические свойства тест-лайнера.

Волокнистая масса готовилась из 100\% макулатуры марки МС-5Б, 2-й сорт. Макулатурная масса размалывалась в мельнице Йокро при концентрации $6 \%$ до $30^{\circ}$ ШР, из размолотой массы изготавливались отливки массой 125 г/м². Исследовались ХВВ производства ООО «СКИФ Спешиал Кемикалз»- «Полиамин ССК», «Полиамин ССК» с увеличенным содержанием аминогрупп, «Ультрафикс Р-127», связующее для упрочнения бумаги (картона) во влажном состоянии - РРУ-1, а также фиксатор «ПОЛИДАДМАХ» (полидиаллилдиметиламмония хлорид) - импортный, анионный полиакриламид (А-ПАМ) и полиоксихлорид алюминия (ПОХА). Химикаты индивидуально или в сочетании добавлялись в массу с определенным удельным расходом.

В качестве контролируемых показателей использовались: для макулатурной массы - ל-потенциал, катионная потребность подсеточной воды: для тест-лайнера - удельное сопротивление разрыву; абсолютное сопротивление продавливанию; энергия межволоконных связи по Скот-Бонду, впитываемость - Кобб 60 , разрывная длина, удельное сопротивление разрыву.

Установлено, что наиболее заметно уменьшает отрицательный 丂-потенциал «Полиамин ССК-М» с увеличенным содержанием аминогрупп (снижение с -13,2 до -5,2 мВ). Примерно так же снижает ל-потенциал «Ультрафикс Р-127», но в сравнении с ним большее влияние оказывает ПОЛИДАДМАХ. Все остальные ХВВ в отдельности и в сочетании

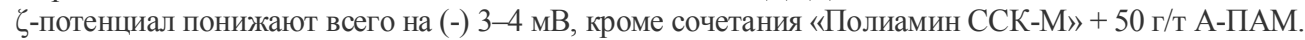

Введение химикатов в большинстве случаев улучшает физико-механические характеристики, за исключением систем с РРЕ-1 для сопротивления продавливанию. Увеличению сопротивления продавливанию способствует добавка Полиамина ССК, при всех дозировках, начиная с малых, наблюдается рост показателя. Полиамин ССК-М дает эффект при дозировках 1,0-1,5 кг/т, ПОЛИДАДМАХ увеличивает сопротивление продавливанию при больших расходах.

Увеличение разрывной длины дает добавка Полиамина ССК, Полиамина ССК-М. Эффективность увеличения падает в ряду: Полиамин ССК, Полиамин ССК-М, Ультрафикс Р-127, ПОЛИДАДМАХ, РРЕ-1, что наиболее четко проявляется при расходах около 1 кг/т.
\end{abstract}

Ключевые слова: макулатура, тест-лайнер, связующее, флоккулянты, фиксаторы, поликатионные полимеры, электрокинетические свойства.

\section{Введение}

В производстве бумаги (картона) применяется широкий ассортимент химических вспомогательных веществ (ХВВ). Они представлены различным классами химических соединений и по функциональности обеспечивают придание новых или изменение имеющихся свойств бумажных материалов [1]. Так, в производстве макулатурного лайнера (тест-лайнера) наиболее востребованными являются фиксаторы, флоккулянты, связующие, гидрофобизаторы, пеногасители, деаэраторы, биоциды [2, 3].

В данной работе исследовано влияние фиксаторов, флоккулянтов и связующего для повышения влагопрочности на электрокинетические свойства макулатурной массы и механические свойства тест-лайнера.

\section{Проведение исследования и анализ результатов}

Кожевников Сергей Юрьевич - руководитель научнотехнических программа развития отдела инновационного развития, кандидат технических наук, e-mail: skif@skif.us
Волокнистая масса готовилась из 100\% макулатуры марки МС-5Б, 2-й сорт. Макулатурная 
масса размалывалась в мельнице Йокро при концентрации 6\% до 30 ШР, из размолотой массы изготавливались отливки массой 125 г/м². При изготовлении отливок на листоотливном аппарате BBS-2 использовалась свежая вода для каждой отливки. При этом содержание волокна в подсеточной воде было минимально - 0,003-0,005 \% и при изменении дозировки химикатов не изменилось. Измеренная величина сопоставима с погрешностью определения, поэтому определения «промоя» волокна не осуществлялось.

Исследовались ХВВ производства ООО «СКИФ Спешиал Кемикалз» - «Полиамин ССК», «Полиамин ССК» с увеличенным содержанием аминогрупп, «Ультрафикс Р-127», связующее для упрочнения бумаги (картона) во влажном состоянии - РРУ-1, а также фиксатор «ПОЛИДАДМАХ» (полидиаллилдиметиламмония хлорид) - импортный, анионный полиакриламид (А-ПАМ) и полиоксихлорид алюминия (ПОХА). Химикаты индивидуально или в сочетании добавлялись в массу с определенным удельным расходом.

В качестве контролируемых показателей применяли: для макулатурной массы - Ђ-потенциал, катионная потребность подсеточной воды: для тест-лайнера - удельное сопротивление разрыву; абсолютное сопротивление продавливанию; энергия межволоконных связи по Скот-Бонду, впитываемость - Кобб разрывная длина, удельное сопротивление разрыву. Результаты экспериментов по влиянию ХВВ на электрокинетические свойства макулатурной массы представлены в таблице 1.

Таблица 1. Влияние ХВВ на электрокинетические свойства макулатурной массы

\begin{tabular}{|c|c|c|c|c|}
\hline $\begin{array}{c}\text { № } \\
\text { XBB }\end{array}$ & $\begin{array}{c}\text { Наименование } \\
\text { и сочетание XВВ }\end{array}$ & Расход, кг/т & 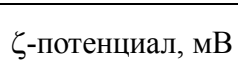 & Катионная потребность, мл \\
\hline 1 & 2 & 3 & 4 & 5 \\
\hline 0 & Без ХВВ & 0 & $-13,3$ & 0,246 \\
\hline 1 & ПОХА & $\begin{array}{l}2,00 \\
4,00\end{array}$ & $\begin{array}{l}-13,2 \\
-12,9\end{array}$ & $\begin{array}{l}0,257 \\
0,209\end{array}$ \\
\hline 2 & $\begin{array}{c}\text { ПОХА } \\
+50 \text { г/ } \text { А А-РAM }\end{array}$ & $\begin{array}{l}2,00 \\
4,00\end{array}$ & $\begin{array}{l}-16,9 \\
-17,8\end{array}$ & $\begin{array}{l}0,241 \\
0,238\end{array}$ \\
\hline 3 & Полиамин ССК & $\begin{array}{l}0,49 \\
0,98 \\
1,46 \\
1,95 \\
2,93\end{array}$ & $\begin{array}{l}-12,1 \\
-11,5 \\
-10,0 \\
-10,0 \\
-8,4\end{array}$ & $\begin{array}{l}0,204 \\
0,151 \\
0,118 \\
0,135 \\
0,085\end{array}$ \\
\hline 4 & $\begin{array}{c}\text { Полиамин ССК+ } \\
50 \text { г/т А-PАМ }\end{array}$ & $\begin{array}{l}0,49 \\
0,98 \\
1,46 \\
1,95 \\
2,93\end{array}$ & $\begin{array}{l}-13,2 \\
-12,1 \\
-12,6 \\
-11,1 \\
-9,1\end{array}$ & $\begin{array}{l}0,204 \\
0,166 \\
0,121 \\
0,116 \\
0,077\end{array}$ \\
\hline 5 & $\begin{array}{l}\text { Полиамин ССК } \\
+80 \text { г/т А-РАМ }\end{array}$ & $\begin{array}{l}0,49 \\
0,98 \\
1,46 \\
1,95 \\
2,93\end{array}$ & $\begin{array}{l}-13,7 \\
-12,5 \\
-12,2 \\
-11,5 \\
-9,6\end{array}$ & $\begin{array}{l}0,185 \\
0,183 \\
0,137 \\
0,108 \\
0,080\end{array}$ \\
\hline 6 & $\begin{array}{c}\text { Полиамин ССК-М } \\
\text { с увеличенным } \\
\text { содержанием } \\
\text { аминогрупп }\end{array}$ & $\begin{array}{l}0,52 \\
1,07 \\
1,55 \\
2,11 \\
3,10\end{array}$ & $\begin{array}{l}-13,2 \\
-11,2 \\
-9,4 \\
-8,5 \\
-5,2\end{array}$ & $\begin{array}{l}0,162 \\
0,141 \\
0,125 \\
0,127 \\
0,108\end{array}$ \\
\hline 7 & $\begin{array}{c}\text { Полиамин ССК-М } \\
\text { с увеличенным } \\
\text { содержанием } \\
\text { аминогрупп } \\
+50 \text { г/т А-PАМ }\end{array}$ & $\begin{array}{l}0,52 \\
1,07 \\
1,55 \\
2,11 \\
3,10\end{array}$ & $\begin{array}{l}-13,3 \\
-11,7 \\
-11,1 \\
-9,5 \\
-8,3\end{array}$ & $\begin{array}{l}0,193 \\
0,152 \\
0,122 \\
0,091 \\
0,085\end{array}$ \\
\hline 8 & $\begin{array}{c}\text { Полиамин ССК-М } \\
\text { с увеличенным } \\
\text { содержанием } \\
\text { аминогрупп } \\
+80 \text { г/т А-PАМ }\end{array}$ & $\begin{array}{l}0,52 \\
1,07 \\
1,55 \\
2,11 \\
3,10\end{array}$ & $\begin{array}{l}-14,1 \\
-12,3 \\
-11,6 \\
-9,9 \\
-8,7\end{array}$ & $\begin{array}{l}0,198 \\
0,151 \\
0,094 \\
0,086 \\
0,085\end{array}$ \\
\hline
\end{tabular}


Окончание таблиџы 1

\begin{tabular}{|c|c|c|c|c|}
\hline 1 & 2 & 3 & 4 & 5 \\
\hline 9 & Ультрафикс Р-127 & $\begin{array}{l}0,30 \\
0,61 \\
0,91 \\
1,21 \\
1,82\end{array}$ & $\begin{array}{c}-13,7 \\
-11,9 \\
-10,6 \\
-10,5 \\
-8,1\end{array}$ & $\begin{array}{l}0,194 \\
0,156 \\
0,097 \\
0,107 \\
0,067\end{array}$ \\
\hline 10 & $\begin{array}{c}\text { Ультрафикс Р-127 } \\
+50 \text { г/т А-PAM }\end{array}$ & $\begin{array}{l}0,30 \\
0,61 \\
0,91 \\
1,21 \\
1,82\end{array}$ & $\begin{array}{l}-13,9 \\
-13,1 \\
-11,9 \\
-10,4 \\
-10,1\end{array}$ & $\begin{array}{l}0,232 \\
0,174 \\
0,168 \\
0,098 \\
0,075\end{array}$ \\
\hline 11 & $\begin{array}{c}\text { Ультрафикс Р-127 } \\
+80 \text { г/т A-PAM }\end{array}$ & $\begin{array}{l}0,30 \\
0,61 \\
0,91 \\
1,21 \\
1,82\end{array}$ & $\begin{array}{l}-14,4 \\
-13,3 \\
-12,4 \\
-11,0 \\
-10,4\end{array}$ & $\begin{array}{l}0,266 \\
0,185 \\
0,116 \\
0,110 \\
0,076\end{array}$ \\
\hline 12 & ПОЛИДАДАМАХ & $\begin{array}{l}0,33 \\
0,66 \\
1,00 \\
1,33 \\
2,00\end{array}$ & $\begin{array}{c}-13,1 \\
-11,4 \\
-9,9 \\
-9,1 \\
-7,2\end{array}$ & $\begin{array}{l}0,214 \\
0,128 \\
0,096 \\
0,071 \\
0,053\end{array}$ \\
\hline 13 & $\begin{array}{c}\text { ПОЛИДАДАМАХ } \\
+50 \text { г/т А-РАМ }\end{array}$ & $\begin{array}{l}0,33 \\
0,66 \\
1,00 \\
1,33 \\
2,00\end{array}$ & $\begin{array}{c}-13,1 \\
-11,9 \\
-10,9 \\
-10,2 \\
-9,5\end{array}$ & $\begin{array}{l}0,183 \\
0,118 \\
0,097 \\
0,090 \\
0,078\end{array}$ \\
\hline 14 & $\begin{array}{c}\text { ПОЛИДАДАМАХ } \\
+80 \text { г/т А-РАМ }\end{array}$ & $\begin{array}{l}0,33 \\
0,66 \\
1,00 \\
1,33 \\
2,00\end{array}$ & $\begin{array}{c}-13,8 \\
-12,1 \\
-11,1 \\
-10,7 \\
-9,8\end{array}$ & $\begin{array}{l}0,214 \\
0,133 \\
0,107 \\
0,081 \\
0,056\end{array}$ \\
\hline 15 & PPE-1 & $\begin{array}{l}0,49 \\
0,99 \\
1,48 \\
1,97 \\
2,96 \\
\end{array}$ & $\begin{array}{l}-13,5 \\
-13,8 \\
-13,6 \\
-13,4 \\
-13,7 \\
\end{array}$ & $\begin{array}{l}0,259 \\
0,260 \\
0,247 \\
0,264 \\
0,271 \\
\end{array}$ \\
\hline 16 & $\begin{array}{c}\text { PPE-1 } \\
+50 \text { г/ А А-PAM }\end{array}$ & $\begin{array}{l}0,49 \\
0,99 \\
1,48 \\
1,97 \\
2,96\end{array}$ & $\begin{array}{l}-16,0 \\
-15,6 \\
-15,0 \\
-16,3 \\
-17,3\end{array}$ & $\begin{array}{l}0,266 \\
0,307 \\
0,285 \\
0,250 \\
0,242\end{array}$ \\
\hline 17 & $\begin{array}{c}\text { PPE-1 } \\
+80 \text { г/т A-PAM }\end{array}$ & $\begin{array}{l}0,49 \\
0,99 \\
1,48 \\
1,97 \\
2,96\end{array}$ & $\begin{array}{l}-15,8 \\
-15,8 \\
-15,3 \\
-16,5 \\
-17,3\end{array}$ & $\begin{array}{l}0,278 \\
0,274 \\
0,304 \\
0,236 \\
0,258\end{array}$ \\
\hline
\end{tabular}

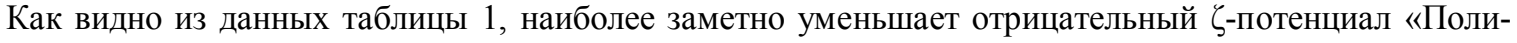
амин ССК-М» (6) с увеличенным содержанием аминогрупп (снижение с -13,2 до -5,2 мВ). Примерно так же снижает ל-потенциал «Ультрафикс Р-127» (9), но в сравнении с ним большее влияние оказывает ПОЛИДАДМАХ (импортный, 12). Все остальные ХВВ в отдельности и в сочетании Ђ-потенциал понижают всего на (-) 3-4 мВ, кроме сочетания «Полиамин ССК-М» + 50 г/т А-ПАМ.

Что касается снижения катионной потребности (характеризует удержание мелкого волокна и иных анионных частиц в изготовленном тест-лайнере), то закономерность следующая: все ХВВ и их сочетания, в большей мере понижающие $\zeta$-потенциал, также больше снижают катионную потребность, т.е. повышают удержание анионных частиц.

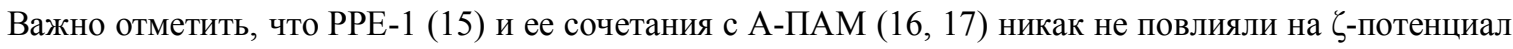
и катионную потребность. 
Зная закономерности влияния исследованных ХВВ на электрокинетические свойства макулатурной массы, важно было получить данные по их влиянию на механические свойства тест-лайнера.

Экспериментальные данные по данной серии исследований представлены в таблице 2.

Таблица 2. Влияние ХВВ на физико-механические показатели тест-лайнера

\begin{tabular}{|c|c|c|c|c|c|c|}
\hline Наименование & $\begin{array}{c}\text { Расход, } \\
\text { кг/т }\end{array}$ & $\begin{array}{c}\text { Сопротив- } \\
\text { ление про- } \\
\text { давливанию, } \\
\text { кПа }\end{array}$ & $\begin{array}{c}\text { Энергия } \\
\text { связи по } \\
\text { Скот- } \\
\text { Бонду, } \\
\text { Дж/м² }\end{array}$ & $\begin{array}{c}\text { Впитыва- } \\
\text { емость, } \\
\text { Коббб } \\
\Gamma_{20}{ }^{2}\end{array}$ & $\begin{array}{c}\text { Разрывная } \\
\text { длина, м }\end{array}$ & $\begin{array}{c}\text { Удельное со- } \\
\text { противление } \\
\text { разрыву, кН/м }\end{array}$ \\
\hline 1 & 2 & 3 & 4 & 5 & 6 & 7 \\
\hline 0 Без ХВВ & 0 & 422 & 198 & 274 & 5050 & 6,41 \\
\hline 1 ПОХА & $\begin{array}{l}2,00 \\
4,00\end{array}$ & $\begin{array}{l}383 \\
417\end{array}$ & $\begin{array}{l}184 \\
177\end{array}$ & $\begin{array}{l}327 \\
329\end{array}$ & $\begin{array}{l}5050 \\
5500\end{array}$ & $\begin{array}{l}6,09 \\
6,69\end{array}$ \\
\hline $\begin{array}{l}2 \text { ПОХА } \\
+50 \text { г/т А-РАМ }\end{array}$ & $\begin{array}{l}2,00 \\
4,00\end{array}$ & $\begin{array}{l}427 \\
397\end{array}$ & $\begin{array}{l}201 \\
191\end{array}$ & $\begin{array}{l}343 \\
329\end{array}$ & $\begin{array}{l}5200 \\
4850\end{array}$ & $\begin{array}{l}6,54 \\
6,08\end{array}$ \\
\hline 3 Полиамин ССК & $\begin{array}{l}0,49 \\
0,98 \\
1,46 \\
1,95 \\
2,93\end{array}$ & $\begin{array}{l}456 \\
467 \\
462 \\
478 \\
486\end{array}$ & $\begin{array}{l}173 \\
174 \\
166 \\
175 \\
170\end{array}$ & $\begin{array}{l}290 \\
342 \\
381 \\
358 \\
360\end{array}$ & $\begin{array}{l}4950 \\
5700 \\
5400 \\
5200 \\
5400\end{array}$ & $\begin{array}{l}6,26 \\
6,99 \\
6,64 \\
6,62 \\
6,68\end{array}$ \\
\hline $\begin{array}{c}4 \text { Полиамин ССК } \\
+50 \text { г/т А-ПАМ }\end{array}$ & $\begin{array}{l}0,49 \\
0,98 \\
1,46 \\
1,95 \\
2,93 \\
\end{array}$ & $\begin{array}{l}400 \\
427 \\
464 \\
491 \\
452\end{array}$ & $\begin{array}{l}182 \\
178 \\
179 \\
171 \\
170\end{array}$ & $\begin{array}{l}302 \\
298 \\
293 \\
358 \\
368\end{array}$ & $\begin{array}{l}4900 \\
5050 \\
5350 \\
5600 \\
5350\end{array}$ & $\begin{array}{l}6,05 \\
6,25 \\
6,59 \\
6,88 \\
6,71 \\
\end{array}$ \\
\hline $\begin{array}{l}5 \text { Полиамин ССК } \\
+80 \text { г/т А-РАМ }\end{array}$ & $\begin{array}{l}0,49 \\
0,98 \\
1,46 \\
1,95 \\
2,93\end{array}$ & $\begin{array}{l}401 \\
418 \\
453 \\
491 \\
496\end{array}$ & $\begin{array}{l}189 \\
178 \\
170 \\
165 \\
174\end{array}$ & $\begin{array}{l}275 \\
299 \\
299 \\
348 \\
354\end{array}$ & $\begin{array}{l}4850 \\
4800 \\
5750 \\
5200 \\
5400\end{array}$ & $\begin{array}{l}5,98 \\
5,83 \\
6,83 \\
6,36 \\
6,74\end{array}$ \\
\hline $\begin{array}{l}\text { 6. Полиамин ССК-М } \\
\text { с увеличенным } \\
\text { содержанием } \\
\text { аминогрупп }\end{array}$ & $\begin{array}{l}0,52 \\
1,07 \\
1,55 \\
2,11 \\
3,10\end{array}$ & $\begin{array}{l}407 \\
443 \\
438 \\
377 \\
409\end{array}$ & $\begin{array}{l}188 \\
176 \\
181 \\
180 \\
180\end{array}$ & $\begin{array}{l}292 \\
344 \\
363 \\
292 \\
291\end{array}$ & $\begin{array}{l}5600 \\
5550 \\
5200 \\
5250 \\
4650\end{array}$ & $\begin{array}{l}6,95 \\
7,09 \\
6,37 \\
6,47 \\
5,80\end{array}$ \\
\hline $\begin{array}{l}7 \text { Полиамин ССК-М } \\
\text { с увеличенным } \\
\text { содержанием } \\
\text { аминогрупп } \\
+50 \text { г/т А-РАМ }\end{array}$ & $\begin{array}{l}0,52 \\
1,07 \\
1,55 \\
2,11 \\
3,10\end{array}$ & $\begin{array}{l}408 \\
442 \\
422 \\
397 \\
470\end{array}$ & $\begin{array}{l}186 \\
182 \\
181 \\
179 \\
185\end{array}$ & $\begin{array}{l}357 \\
372 \\
388 \\
394 \\
421\end{array}$ & $\begin{array}{l}4950 \\
4950 \\
4550 \\
4400 \\
5350\end{array}$ & $\begin{array}{l}6,07 \\
6,12 \\
5,56 \\
5,57 \\
6,88\end{array}$ \\
\hline $\begin{array}{l}\text { 8. Полиамин ССК-М } \\
\text { с увеличенным } \\
\text { содержанием } \\
\text { аминогрупп } \\
+80 \text { г/т А-PAM }\end{array}$ & $\begin{array}{l}0,52 \\
1,07 \\
1,55 \\
2,11 \\
3,10\end{array}$ & $\begin{array}{l}406 \\
432 \\
468 \\
451 \\
441\end{array}$ & $\begin{array}{l}179 \\
180 \\
184 \\
185 \\
184\end{array}$ & $\begin{array}{l}361 \\
380 \\
406 \\
400 \\
387\end{array}$ & $\begin{array}{l}4750 \\
5300 \\
4850 \\
4850 \\
5050\end{array}$ & $\begin{array}{l}5,91 \\
6,46 \\
6,15 \\
6,08 \\
6,14\end{array}$ \\
\hline 9 Ультрафикс Р-127 & $\begin{array}{l}0,30 \\
0,61 \\
0,91 \\
1,21 \\
1,82 \\
\end{array}$ & $\begin{array}{l}416 \\
443 \\
422 \\
446 \\
469 \\
\end{array}$ & $\begin{array}{l}184 \\
182 \\
198 \\
166 \\
180 \\
\end{array}$ & $\begin{array}{l}356 \\
368 \\
371 \\
339 \\
331 \\
\end{array}$ & $\begin{array}{l}5300 \\
5250 \\
5200 \\
5250 \\
5200 \\
\end{array}$ & $\begin{array}{l}6,65 \\
6,52 \\
6,43 \\
6,46 \\
6,39 \\
\end{array}$ \\
\hline $\begin{array}{l}10 \text { Ультрафикс Р-127 } \\
+50 \text { г/т А-РАМ }\end{array}$ & $\begin{array}{l}0,30 \\
0,61 \\
0,91 \\
1,21 \\
1,82\end{array}$ & $\begin{array}{l}439 \\
447 \\
425 \\
478 \\
479\end{array}$ & $\begin{array}{l}189 \\
186 \\
179 \\
182 \\
180\end{array}$ & $\begin{array}{l}351 \\
382 \\
406 \\
397 \\
414\end{array}$ & $\begin{array}{l}5100 \\
5200 \\
5200 \\
5300 \\
5450\end{array}$ & $\begin{array}{l}6,35 \\
6,56 \\
6,29 \\
6,83 \\
6,89\end{array}$ \\
\hline $\begin{array}{l}11 \text { Ультрафикс Р-127 } \\
+80 \text { г/т А-РАМ }\end{array}$ & $\begin{array}{l}0,30 \\
0,61 \\
0,91 \\
1,21 \\
1,82 \\
\end{array}$ & $\begin{array}{l}435 \\
449 \\
451 \\
430 \\
469 \\
\end{array}$ & $\begin{array}{l}182 \\
186 \\
182 \\
187 \\
169 \\
\end{array}$ & $\begin{array}{l}335 \\
386 \\
375 \\
421 \\
426 \\
\end{array}$ & $\begin{array}{l}5050 \\
5050 \\
5200 \\
5100 \\
5200\end{array}$ & $\begin{array}{l}6,37 \\
6,16 \\
6,44 \\
6,36 \\
6,42 \\
\end{array}$ \\
\hline
\end{tabular}


Окончание таблицы 2

\begin{tabular}{|c|c|c|c|c|c|c|}
\hline 1 & 2 & 3 & 4 & 5 & 6 & 7 \\
\hline \multirow{5}{*}{$\begin{array}{l}\text { 12. ПОЛИДАДМАХ } \\
\text { (импортный) }\end{array}$} & 0,33 & 403 & 195 & 298 & 5100 & 6,33 \\
\hline & 0,66 & 401 & 176 & 328 & 5150 & 6,28 \\
\hline & 1,00 & 444 & 171 & 463 & 4950 & 6,09 \\
\hline & 1,33 & 428 & 174 & 358 & 4850 & 5,83 \\
\hline & 2,00 & 466 & 164 & 401 & 5500 & 6,72 \\
\hline \multirow{5}{*}{$\begin{array}{l}\text { 13. ПОЛИДАДМАХ } \\
+50 \text { г/т А-РАМ }\end{array}$} & 0,33 & 436 & 186 & 372 & 4800 & 6,07 \\
\hline & 0,66 & 471 & 182 & 420 & 4750 & 6,11 \\
\hline & 1,00 & 449 & 177 & 395 & 4850 & 6,04 \\
\hline & 1,33 & 481 & 178 & 398 & 5300 & 6,88 \\
\hline & 2,00 & 482 & 176 & 408 & 5600 & 7,04 \\
\hline \multirow{5}{*}{$\begin{array}{l}\text { 14. ПОЛИДАДМАХ } \\
+80 \text { г/ А-РАМ }\end{array}$} & 0,33 & 437 & 171 & 329 & 4800 & 5,98 \\
\hline & 0,66 & 437 & 170 & 380 & 5050 & 6,26 \\
\hline & 1,00 & 435 & 172 & 374 & 5300 & 6,70 \\
\hline & 1,33 & 451 & 168 & 370 & 4850 & 5,84 \\
\hline & 2,00 & 478 & 163 & 371 & 5300 & 6,63 \\
\hline \multirow[t]{5}{*}{ 15. PPE-1 } & 0,49 & 393 & 186 & 340 & 4850 & 5,91 \\
\hline & 0,99 & 413 & 187 & 342 & 4900 & 6,02 \\
\hline & 1,48 & 411 & 182 & 309 & 4950 & 5,93 \\
\hline & 1,97 & 410 & 189 & 277 & 5100 & 6,20 \\
\hline & 2,96 & 404 & 175 & 270 & 5000 & 5,96 \\
\hline \multirow{5}{*}{$\begin{array}{l}\text { 16. РPE-1 } \\
+50 \text { г/т А-PAM }\end{array}$} & 0,49 & 425 & 188 & 280 & 4950 & 6,14 \\
\hline & 0,99 & 435 & 186 & 305 & 5050 & 6,20 \\
\hline & 1,48 & 450 & 185 & 276 & 5250 & 6,65 \\
\hline & 1,97 & 411 & 184 & 268 & 5300 & 6,55 \\
\hline & 2,96 & 425 & 188 & 252 & 5000 & 6,30 \\
\hline \multirow{5}{*}{$\begin{array}{l}17 \text { PPE-1 } \\
+80 \text { г/т А-PAM }\end{array}$} & 0,49 & 407 & 174 & 262 & 4850 & 5,92 \\
\hline & 0,99 & 414 & 188 & 236 & 5100 & 6,28 \\
\hline & 1,48 & 412 & 182 & 328 & 4900 & 6,14 \\
\hline & 1,97 & 424 & 182 & 337 & 4900 & 6,00 \\
\hline & 2,96 & 418 & 188 & 326 & 5300 & 6,59 \\
\hline
\end{tabular}

Влияние добавок химикатов в различных дозировках без добавок А-РАМ на физико-механические свойства образцов представлено на рисунках 1 и 2. Введение химикатов в большинстве случаев улучшает физико-механические характеристики, за исключением систем с PPE-1 для сопротивления продавливанию. Увеличению сопротивления продавливанию способствует добавка Полиамина ССК. При всех дозировках, начиная с малых, наблюдается рост показателя (рис. 1a). Полиамин ССК-М дает эффект при дозировках 1,0-1,5 кг/т, ПОЛИДАДМАХ увеличивает сопротивление продавливанию при больших расходах.

Увеличение разрывной длины дает добавка Полиамина ССК, Полиамина ССК-М (рис. 1б). Эффективность увеличения падает в ряду: Полиамин ССК, Полиамин ССК-М, Ультрафикс Р-127, ПОЛИДАДMAX, PРЕ-1, что наиболее четко проявляется при расходах около 1 кг/т.

Снижению поверхностной впитываемости в наибольшей степени способствует добавка Полиамина ССК (рис. 2a). При этом положительный результат дают все химикаты. Отметим, что впитываемость имеет очень высокие значения, поскольку гидрофобизирующие компоненты не вводились.

На рисунке 1а видно, что сопротивление продавливанию заметно возрастает только при добавках химикатов Полимин ССК, Полимин ССК-М, Ультрафикс Р-127 и ПОЛИДАДМАХ. Наибольшее увеличение разрывной длины наблюдается при добавке РPЕ-1 0,5 кг/т и Полиамина ССК (рис. 1б).

Увеличение энергии связи (рис. 2б) наблюдается при использовании всех химикатов в дозировках 0,5-1,5 кг/т. Дальнейшее увеличение расходов нецелесообразно. Большая энергия связи наблюдается при добавлении химиката ПОЛИДАДМАХ, увеличение практически в 1,5-2,0 раза.

Большая поверхностная впитываемость (рис. 2а) объясняется отсутствием добавки в массу гидрофобизирующего вещества. Тем не менее, она существенно снижается при добавках большинства химикатов. Особенно заметен эффект от Полиамин ССК.

На рисунках 3-8 представлены графики, отражающие влияние дозировки и добавки А-РАМ на электрокинетические свойства бумажной массы и механическую прочность тест-лайнера по каждому из исследованных химикатов. 

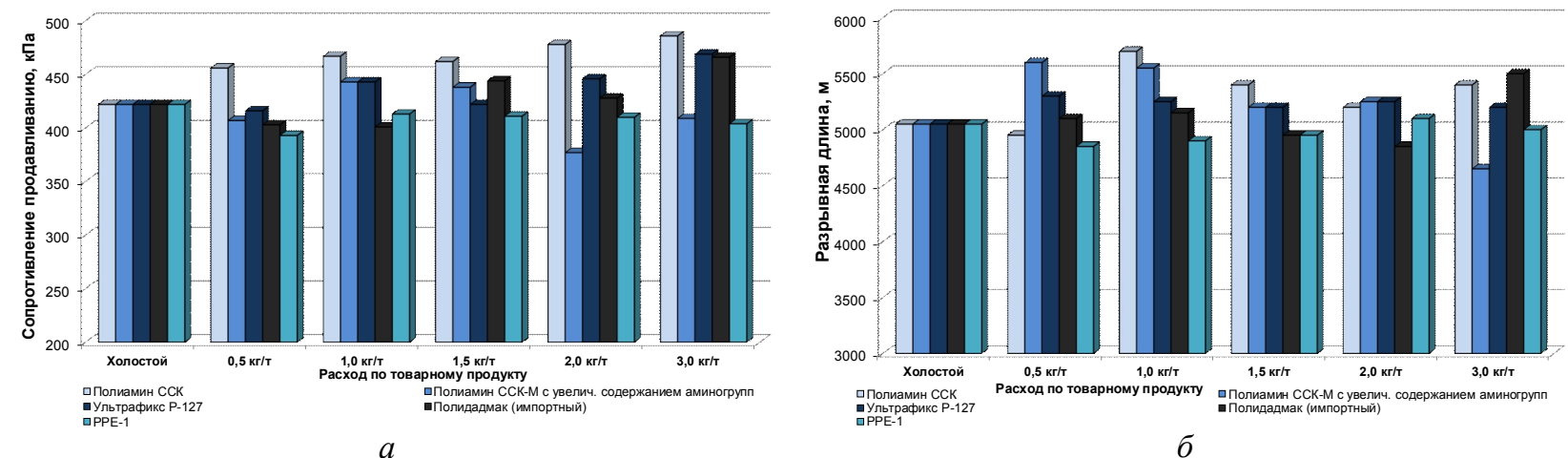

Рис. 1. Влияние XВВ на сопротивление продавливанию и разрывную длину макулатурного лайнера
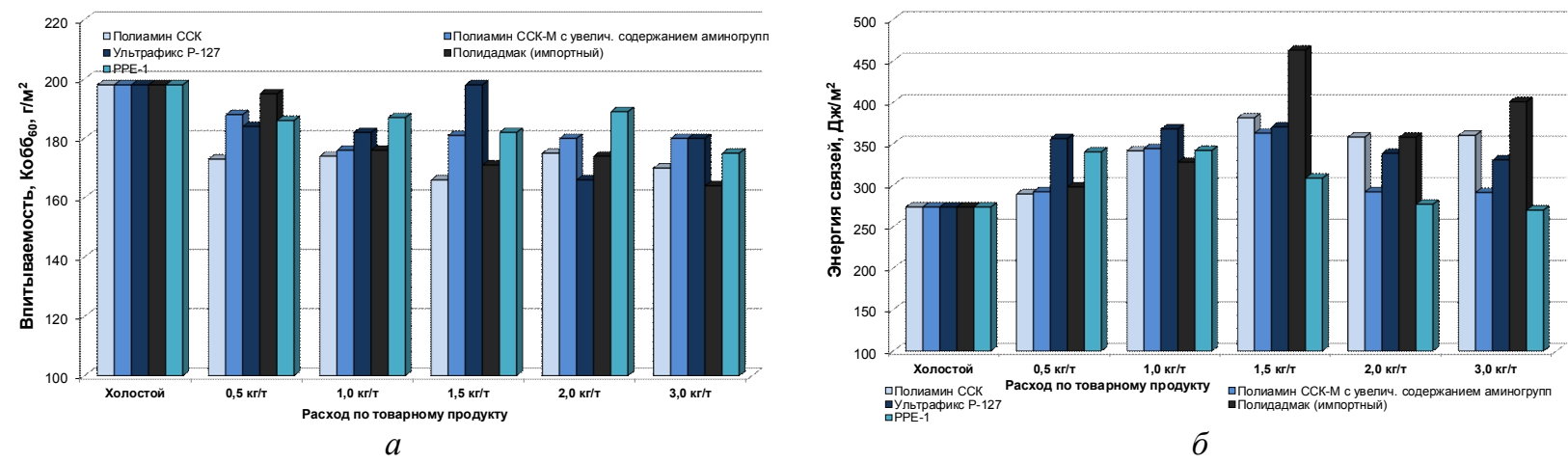

Рис. 2. Влияние ХВВ на впитываемость при одностороннем смачивании и энергию связи макулатурного лайнера

Как видно на рисунке 3, добавка А-РАМ к Полиамин ССК не дают положительного результата: не снижается ל-потенциал, возрастает катионная потребность, увеличивается впитываемость, снижаются энергия связей, сопротивление продавливанию, прочность при растяжении.

Из рисунка 4 следует, что модифицированный Полиамин ССК-М с увеличенным содержанием аминогрупп усиливает свое действие при введении А-РАМ. Несмотря на некоторое повышение 丂-потенциала, катионная потребность снижается при дозировках более 1 кг/т, несколько увеличивается сопротивление продавливанию. Впитываемость остается практически на том же уровне, а энергия связей возрастает.

На рисунке 5 видно, что добавка А-РАМ к Ультрафикс Р-127 не приводит к снижению ни

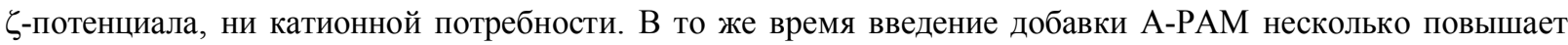
сопротивление продавливанию и энергию связей. Зато прочность при растяжении несколько снижается. На впитываемости заметного влияния не прослеживается.

Как видно на рисунке 6, добавка А-РАМ к ПОЛИДАДМАХ дает эффект, аналогичный наблюдаемому для Ультрафикс Р-127: добавка А-РАМ несколько снижает эффект от улучшения электрокинетических характеристик бумажной массы (увеличиваются ל-потенциал и катионная потребность). Из механических характеристик - увеличивается сопротивление продавливанию, разрывная длина при малых дозировках ПОЛИДАДМАХ несколько снижается, а при больших - несколько увеличивается. Впитываемость снижается при малых дозировках, а энергия связей возрастает.

Особый характер влияния на свойства бумажной массы и картона имеет связующее РРЕ-1 (рис. 7). Ни оно само, ни добавка А-РАМ не приводят к снижению 丂-потенциала и катионной потребности. Положительный эффект от добавки А-РАМ не отмечен.

Добавки ПОХА отдельно и с А-ПАМ не изменяют 丂-потенциал, мало влияют на катионную потребность, разрывную длину, но несколько снижают впитываемость и увеличивают энергию связи (рис. 8). 


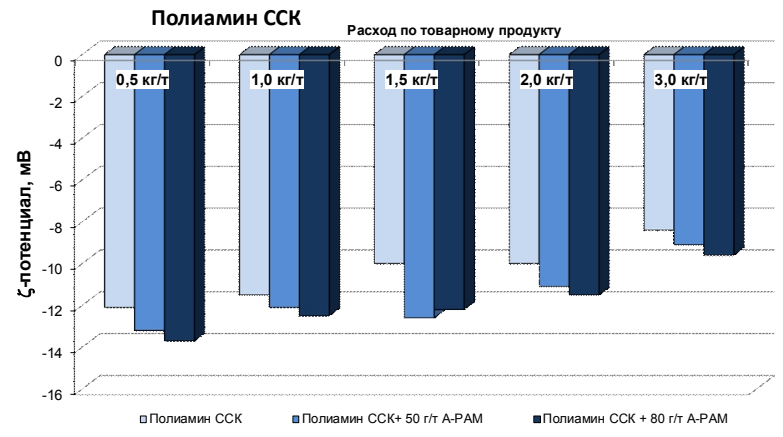

a
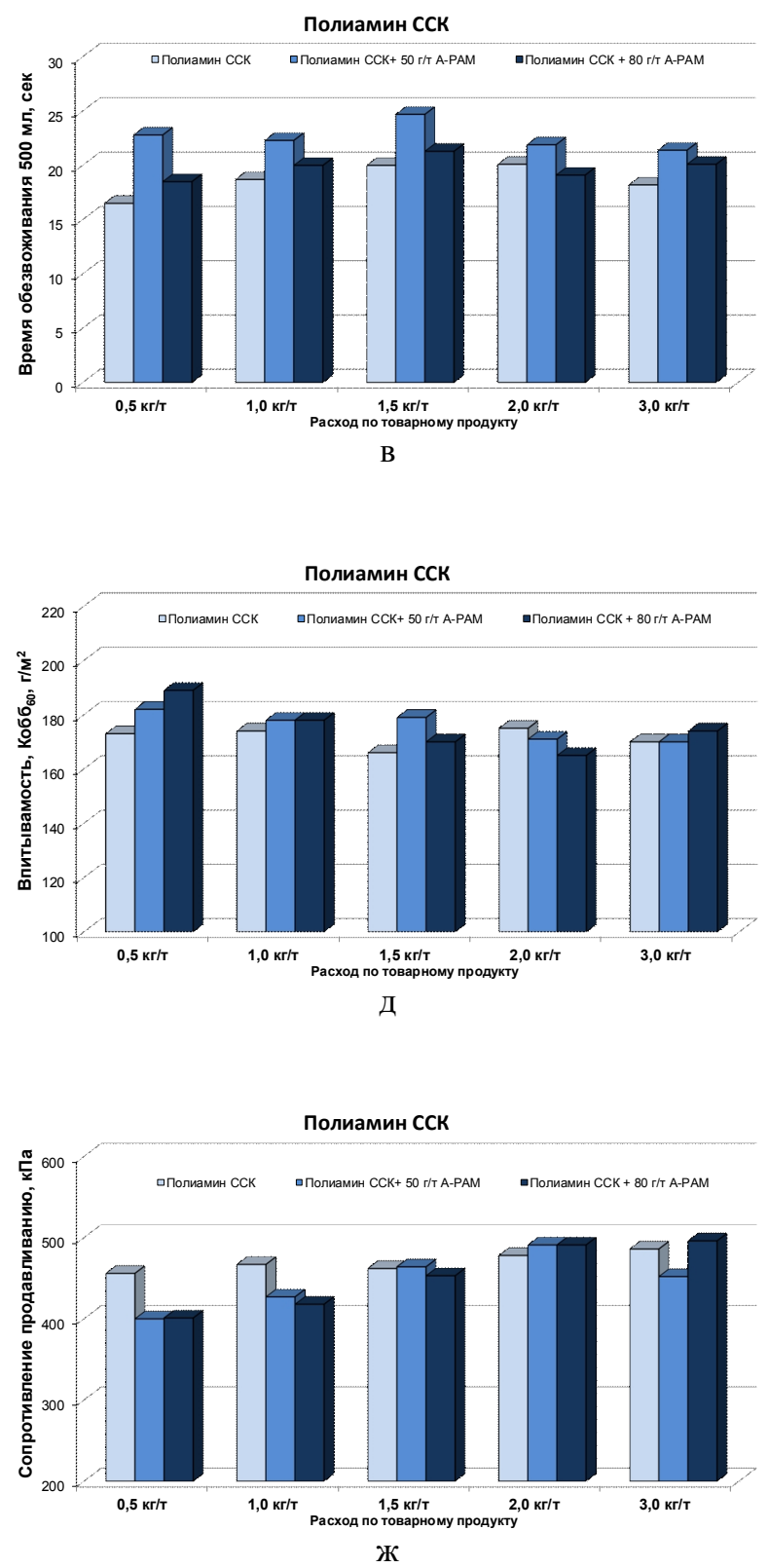
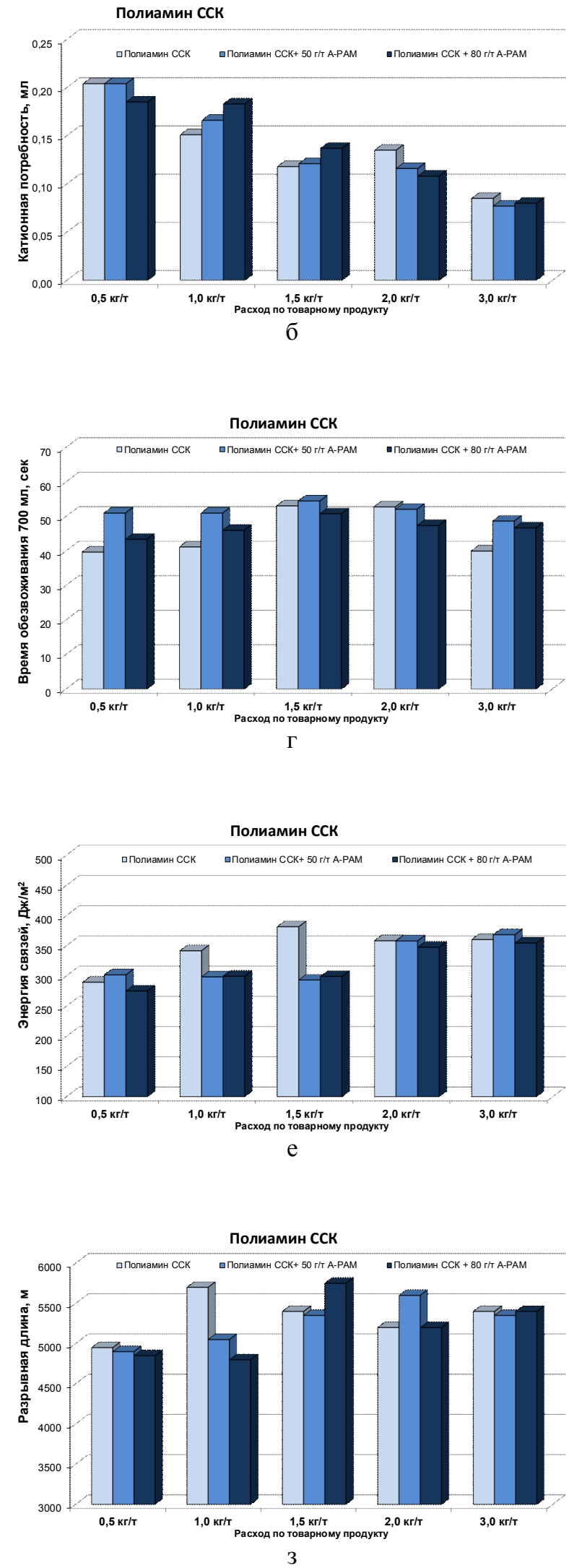

Рис. 3. Влияние дозировки Полиамин ССК добавки А-ПАМ на свойства макулатурной массы и тестлайнера 


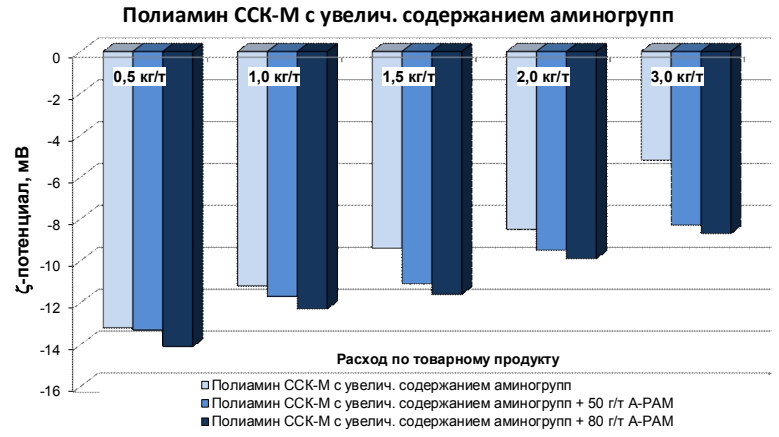

a
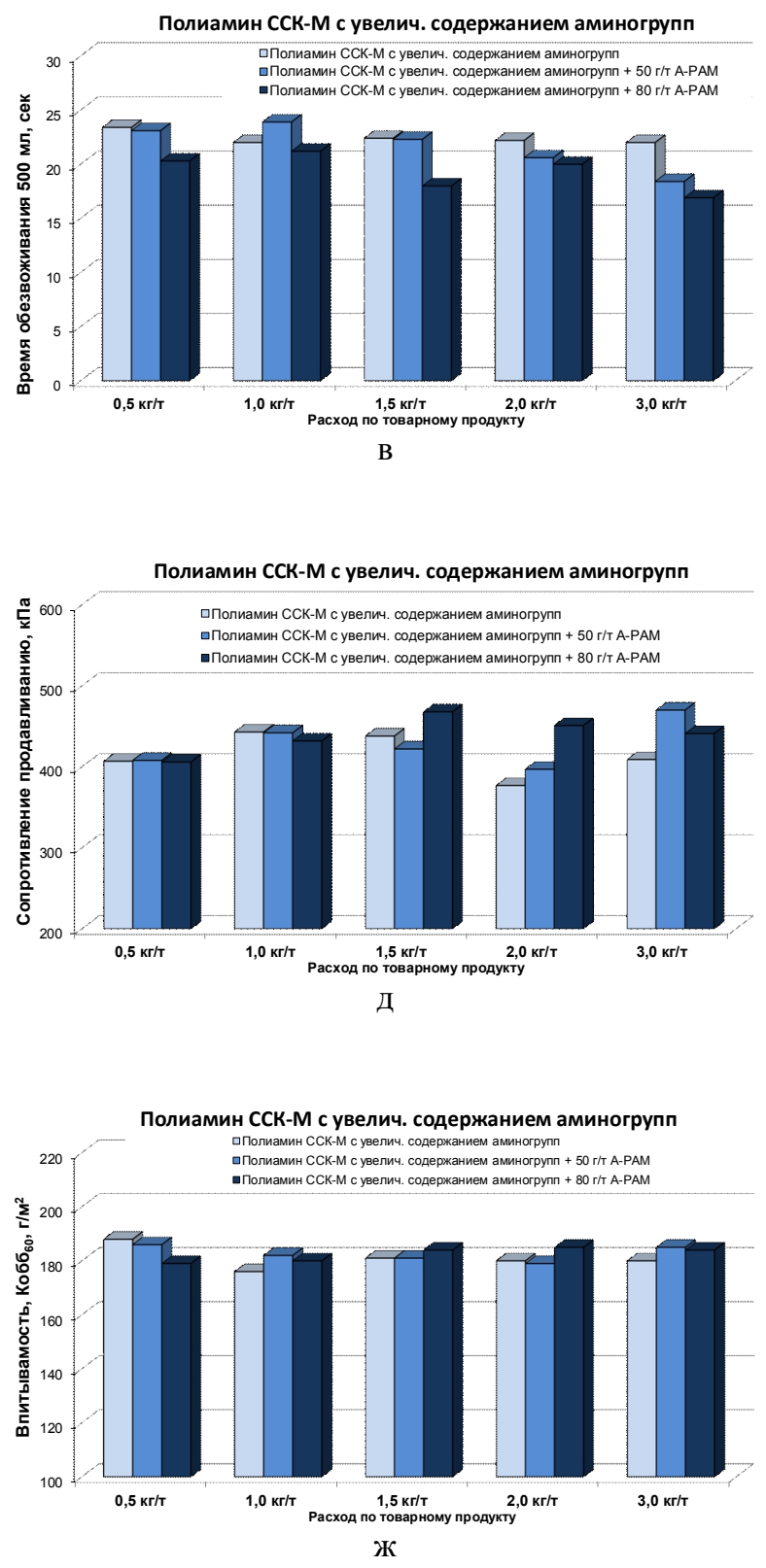
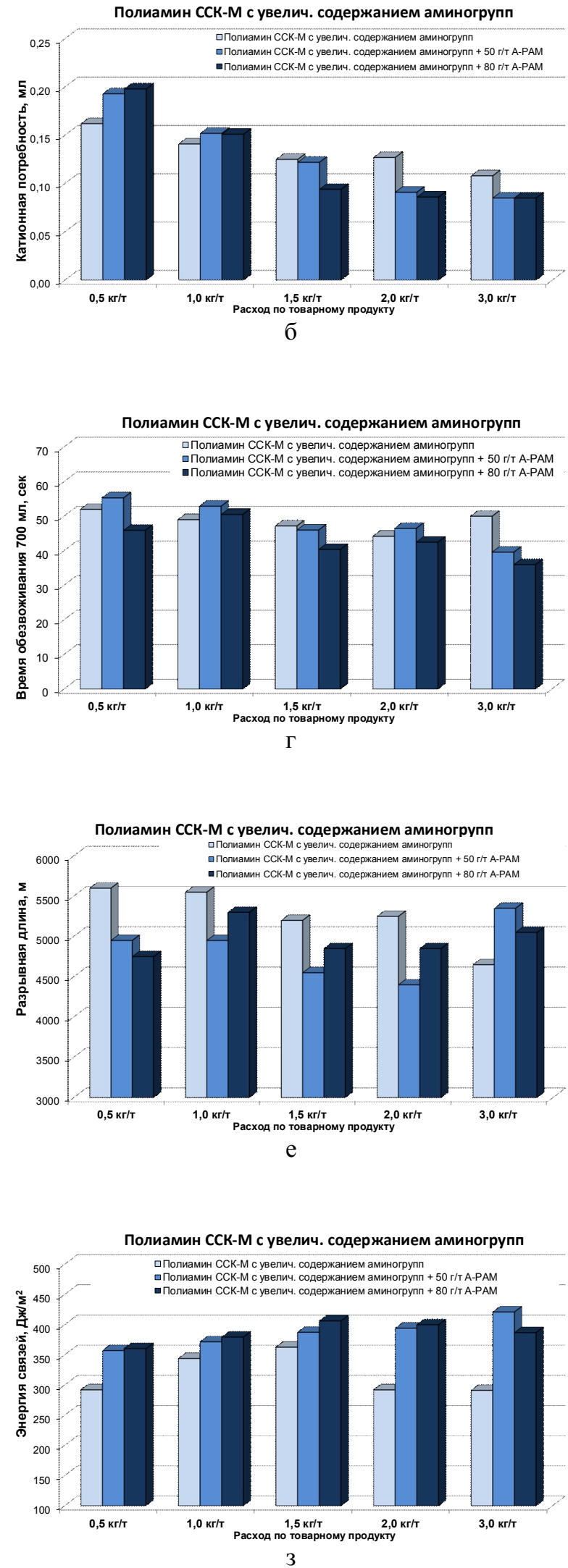

Рис. 4. Влияние дозировки Полиамин ССК-М с увеличенным содержанием аминогрупп и добавки А-РАМ на свойства макулатурной массы и тест-лайнера 


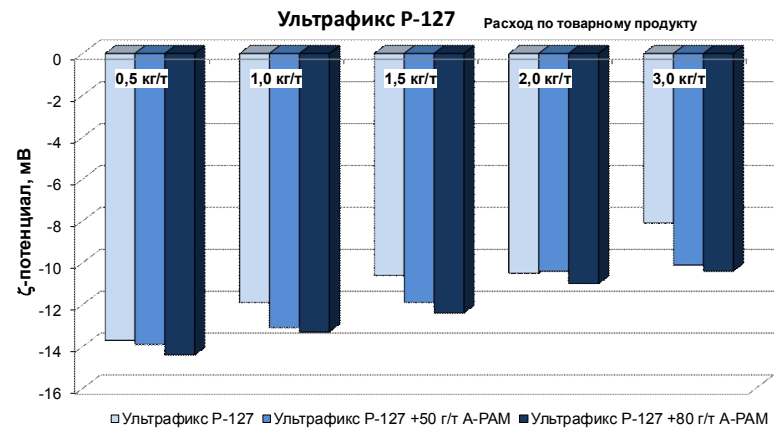

a
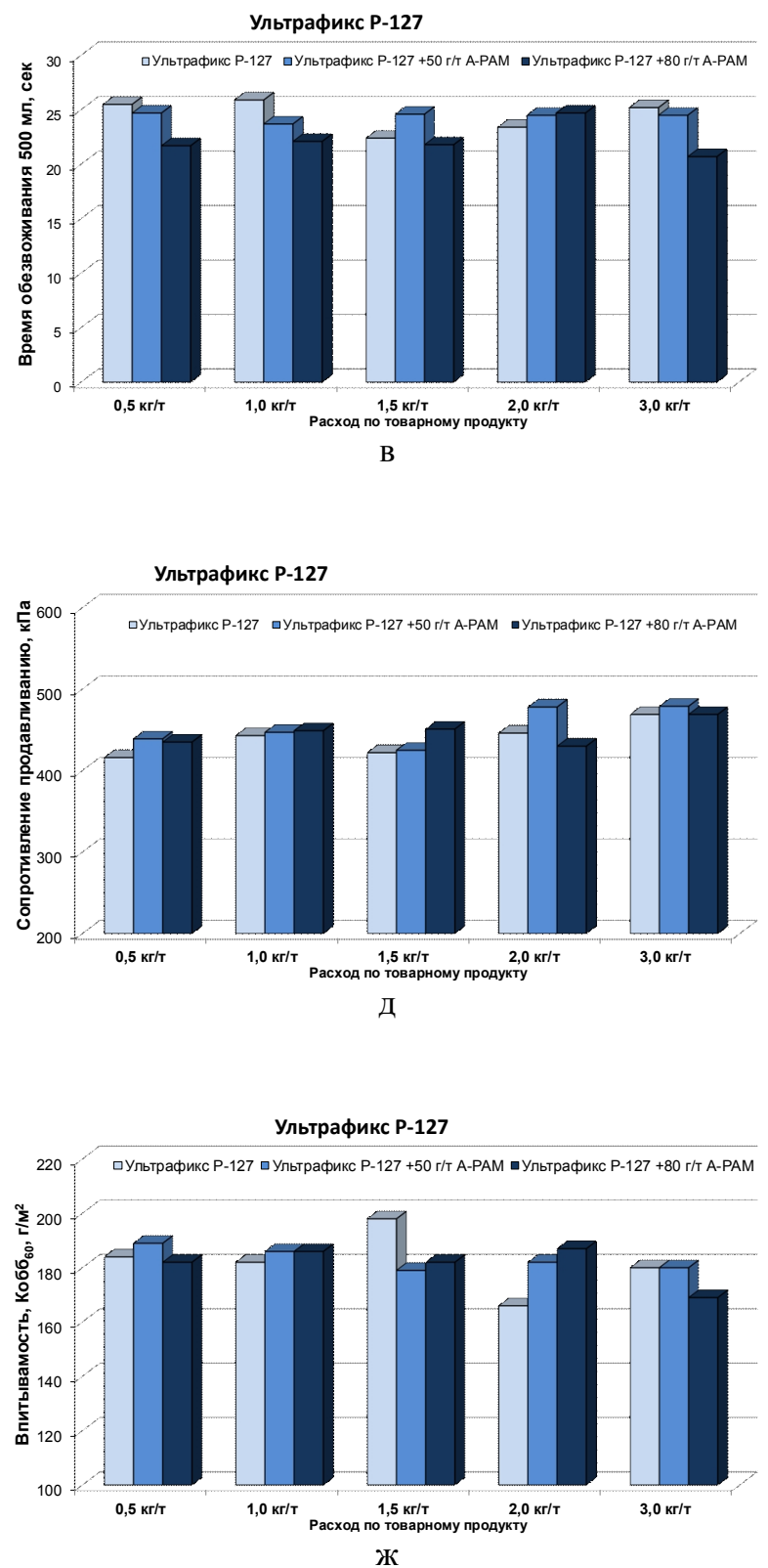
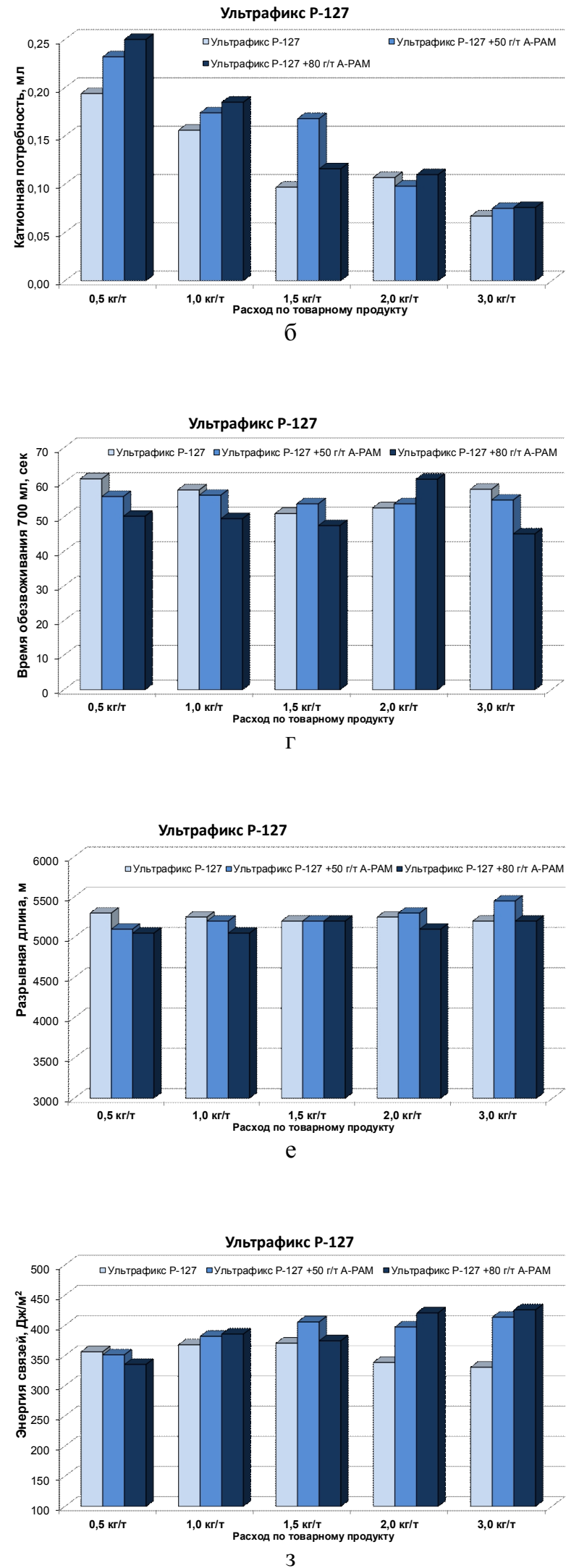

Рис. 5. Влияние дозировки Ультрафикс Р-127 и добавки А-РАМ на свойства макулатурной массы и тестлайнера 


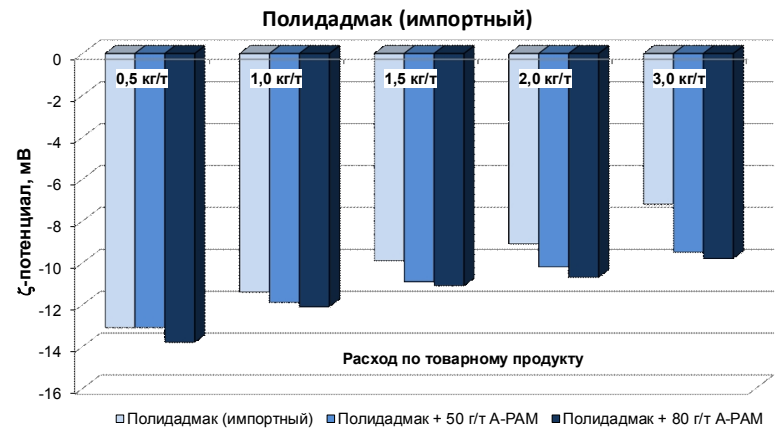

a
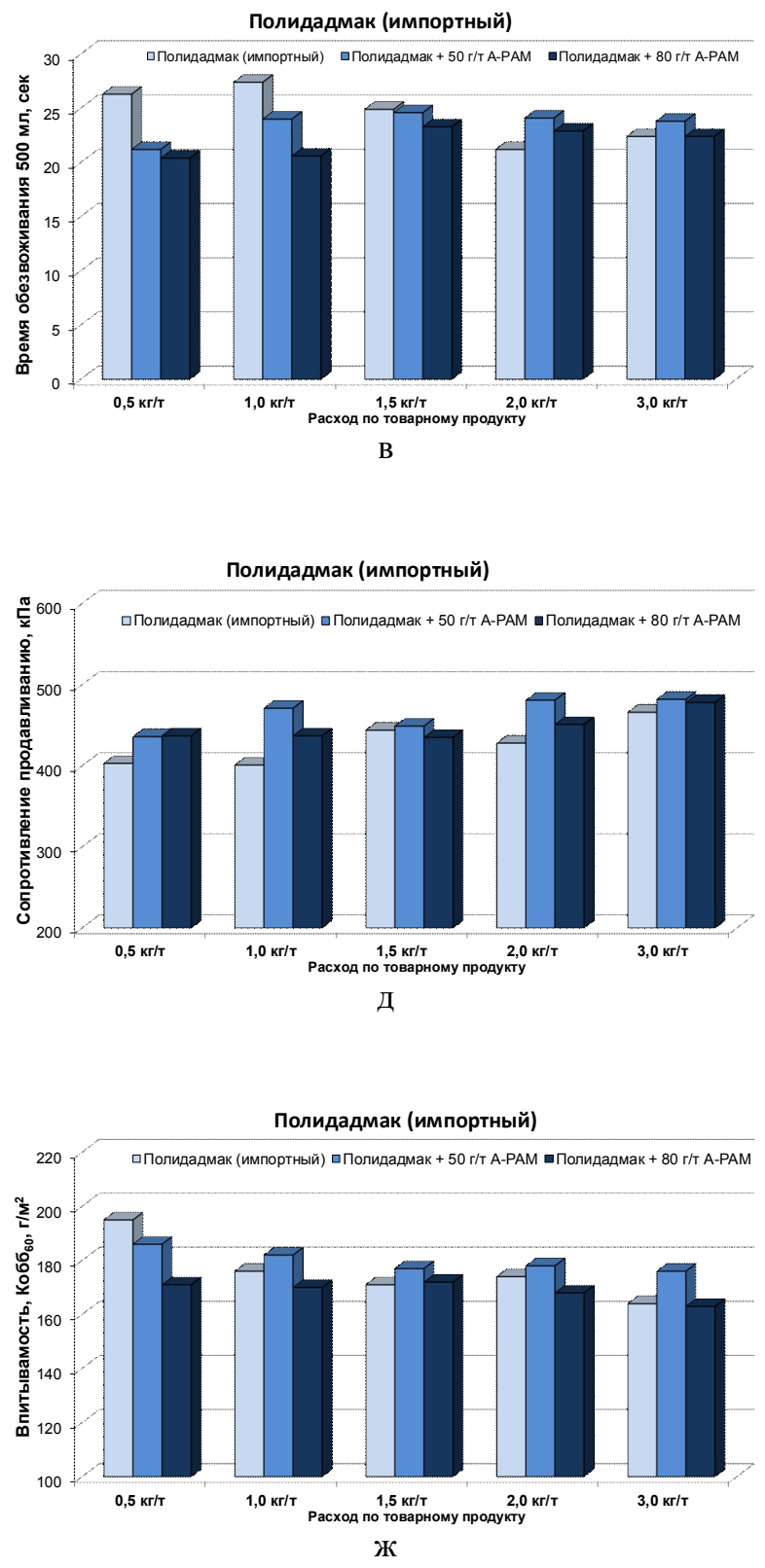
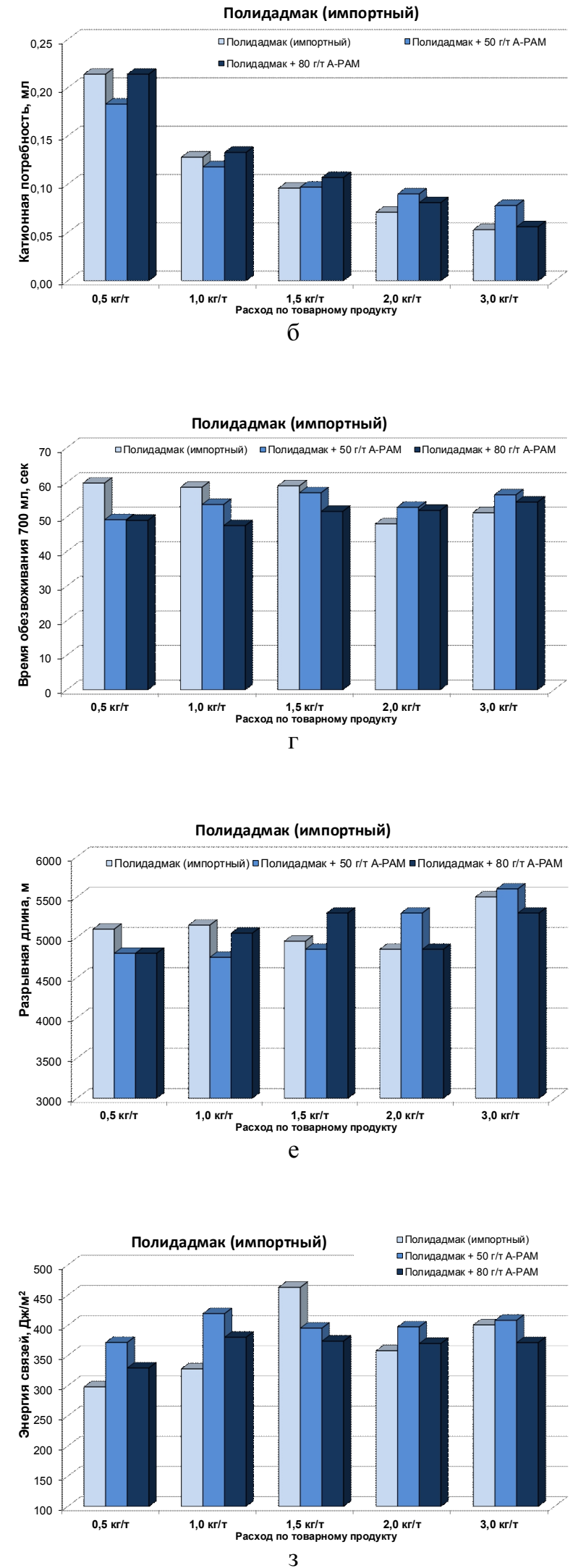

Рис. 6. Влияние дозировки ПОЛИДАДМАХ и А-ПАМ на свойства макулатурной массы и тест-лайнера 


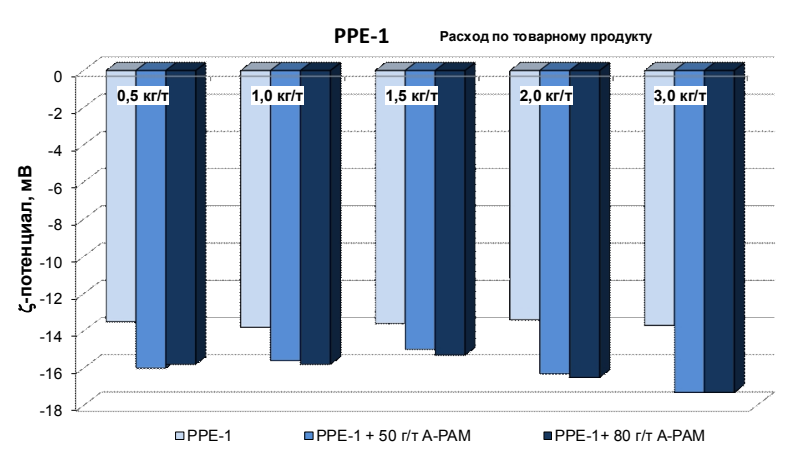

a
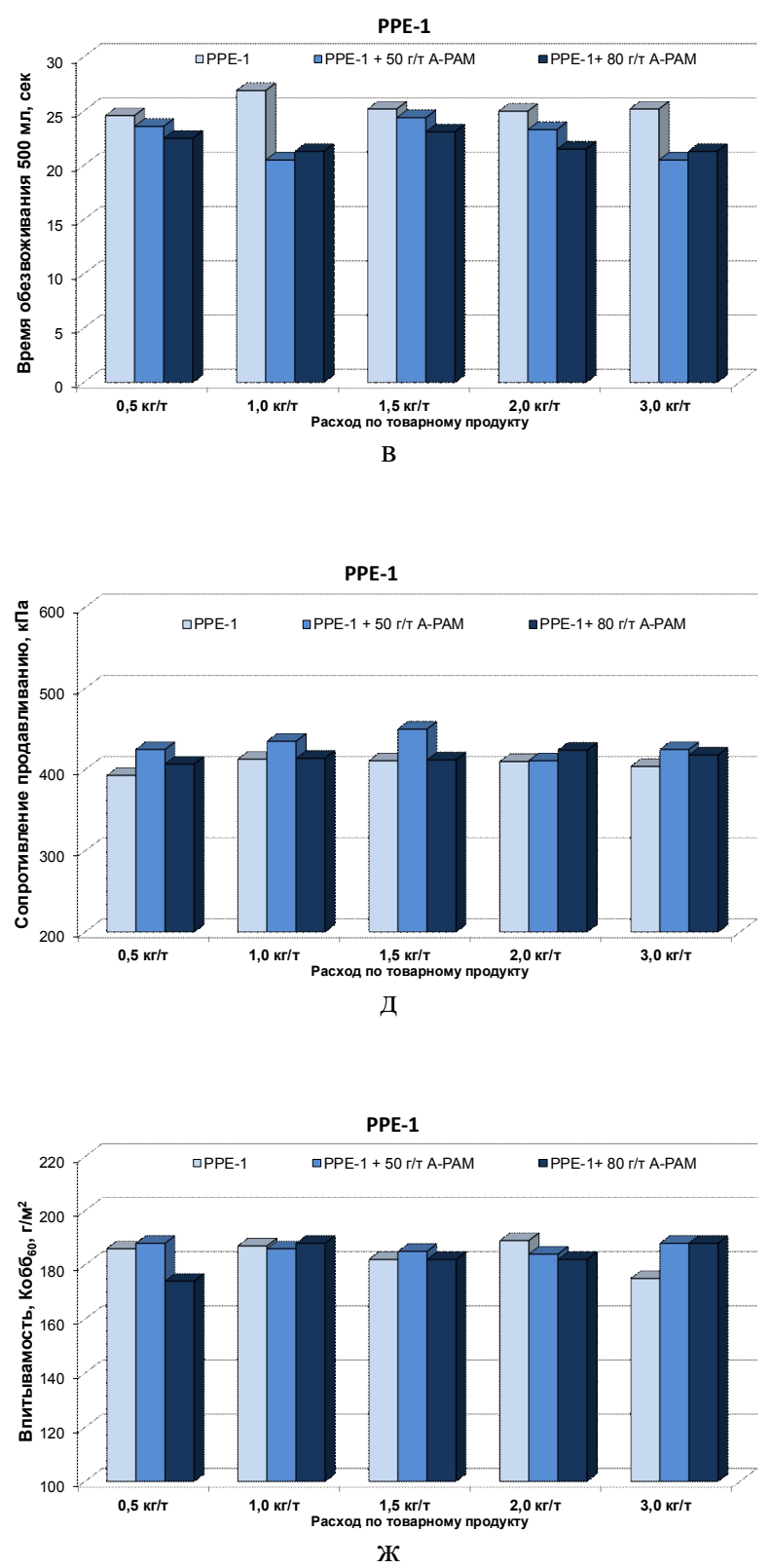
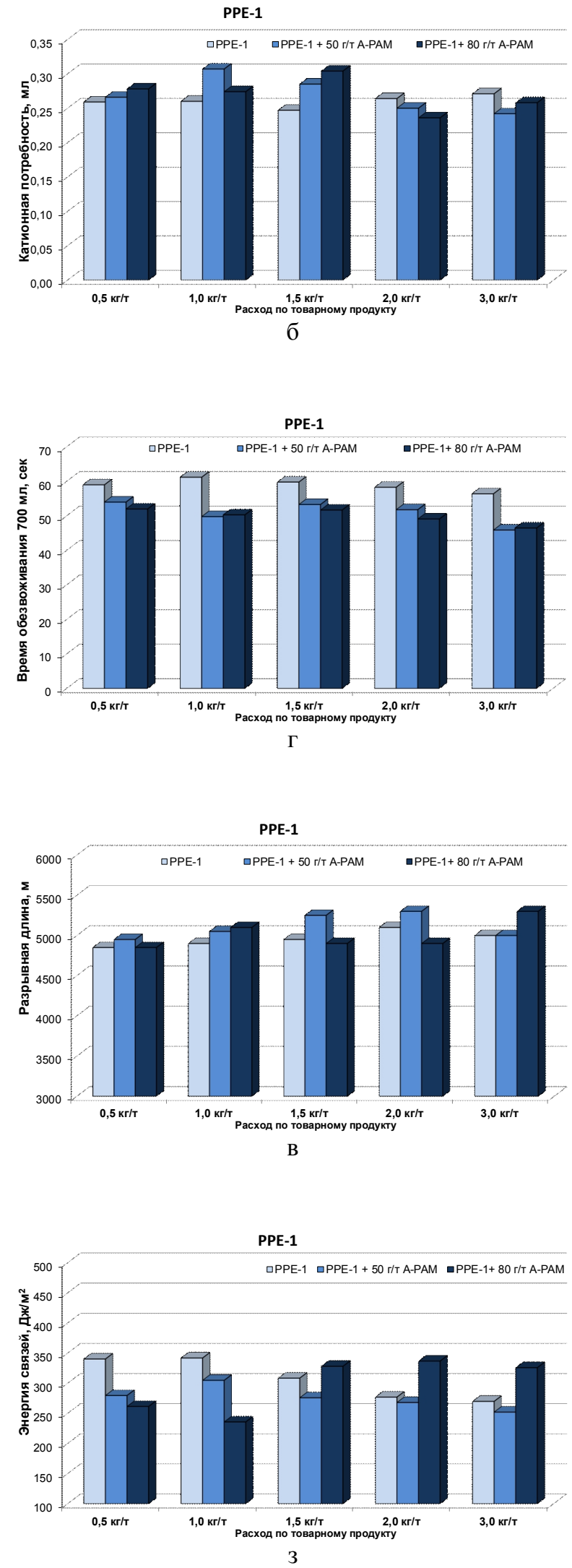

Рис. 7. Влияние дозировки РPЕ-1 и добавки А-РАМ на свойства макулатурной массы и тест-лайнера 

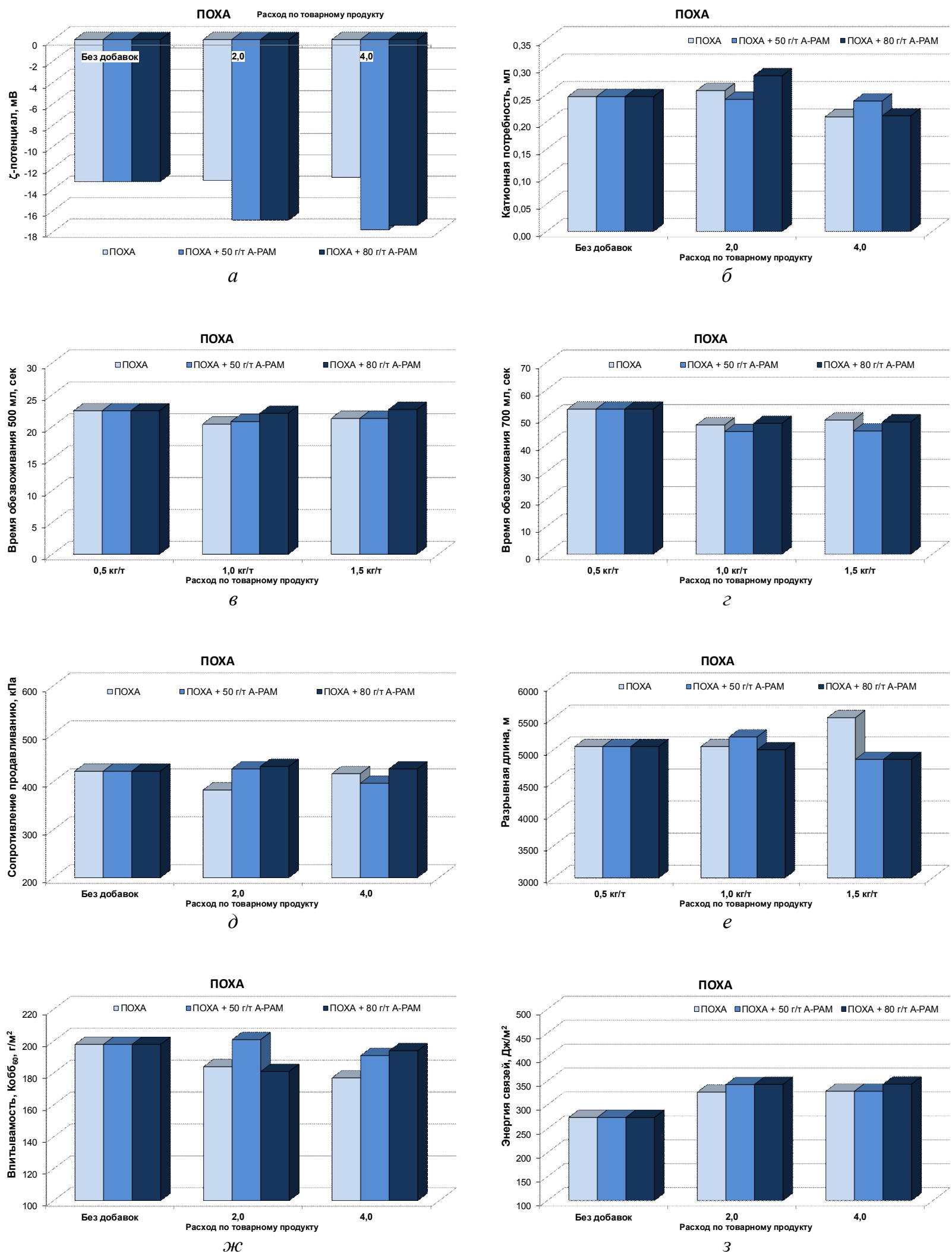

Рис. 8. Влияние дозировки ПОХА и добавки А-РАМ на свойства макулатурной массы и тест-лайнера

\section{Bыводы}

При исследовании добавок в композицию макулатурной массы ХВВ установлены следующие закономерности:

а) увеличение дозировки в большинстве случае снижает Ђ-потенциал на 3-4 мВ; введение PРЕ-1 практически не влияет на изменение ל-потенциала; 
б) введение химикатов позволяет снизить катионную потребность макулатурной массы с 0,25 до 0,12-0,10 мл;

в) пенообразование наблюдались в сериях экспериментов с Полиамин ССК, Полиамин ССК-М, Ультрафикс Р-127, ПОЛИДАДМАК, при повышенных расходах химикатов; введение А-РАМ усиливает склонность к пенообразованию массы с Полиамин ССК-М;

г) введение химикатов в большинстве случаев улучшает физико-механические характеристики за исключением систем с РРЕ-1 для сопротивления продавливанию;

д) добавка А-РАМ несколько улучшает электрокинетические характеристики бумажной массы при совместном использовании химикатов: увеличиваются ל-потенциал и катионная потребность;

е) добавка А-РАМ не приводит к существенному изменению физико-механических характеристик макулатурного картона.

\section{Список литературы}

1. Иванов С.И. Технология бумаги. М., 2006. 696 с.

2. Кожевников С.Ю., Вдовина О.С., Ковернинский И.Н. Химические продукты и инновации «СКИФ Спешиал Кемикалз» для бумаги и картона // Целлюлоза. Бумага. Картон. 2015. №5. С. 64-66.

3. Шабиев Р.О., Смолин А.С., Ковернинский И.Н., Кожевников С.Ю. Химия бумаги: исследование действия упрочняющих и обезвоживающих добавок // Химия растительного сырья. 2014. №4. С. 263-270.

Поступило в редакичию 20 января 2016 г.

После переработки 25 февраля 2016 г. 


\section{Kozhevnikov S.Yu. STUDY OF POLYMERS POLIKATIONIC ELECTROKINETIC PROPERTIES OF DEINKING AND MECHANICAL STRENGTH OF TESTLINER}

Limited Liability Company "SKIF Special Chemicals", Vostochnaja promzona, 7, Dzerzhinsk, Nizhny Novgorod region, 606000 (Russia),e-mail: skif@skif.us

Effect of fixatives, flocculants and binder to improve wet strength on electrokinetic properties of deinking and mechanical properties of test liner investigated.

The pulp was prepared from $100 \%$ waste paper grade MS-5B, 2nd grade. Deinking Yokro milled in a mill at a concentration of $6 \%$ to $30{ }^{\circ} \mathrm{SHR}$ and milled mass produced from castings weighing $125 \mathrm{~g} / \mathrm{m}^{2}$. Investigated HVV produced by "SKIF Special Chemicals" - "Polyamine SSC", "Polyamine CCK" with an increased content of amino groups "Ultrafiks P-127", a binder for strengthening paper (cardboard) wet - RRU 1 and retainer "polyDADMAC"(polydiallyldimethylammonium chloride) - import, anionic polyacrylamide (A-PAM) and aluminum polyoxychloride (Pohang). Chemicals individually or in combination added to the mass with certain specific consumption.

As indicators were monitored: for wastepaper - the $\zeta$-potential cationic demand subgrid water: for test liner - specific tensile strength; absolute bursting; interfiber binding energy by Scott-Bond, absorbency - Kobb60, breaking length, tear resistivity.

It was found that most significantly reduces the $\mathrm{z}-$ potential of negative "polyamine CCK-M" with increased content of amino groups (a decline from -13.2 to $-5.2 \mathrm{mV}$ ). Approximately also reduces $\zeta$-potential "Ultrafiks P-127", but, by comparison, has a greater influence polyDADMAC. All other HVV alone and in combination $\zeta$-potential is lowered only $(-) 3.4 \mathrm{mV}$, except combinations "Polyamine CCK-M" + $50 \mathrm{~g} / \mathrm{t}$ A-PAM.

The introduction of chemicals in most cases improved physical and mechanical properties, except for systems with PPE-1 resistance to bursting. CCK polyamine additive increases bursting resistance at all doses, ranging from small, the growth rate is observed. M CCK-polyamine gives effect at dosages of 1,0-1,5 kg/t polyDADMAC increases the burst strength at high flow rates.

Increased breaking length gives additive polyamine SSC, SSC polyamine-M. Efficiency increase in the number of falls: CCK polyamine, polyamine CCK-M Ultrafiks P-127, polyDADMAC, PPE-1, which is most clearly manifested at a rate of about $1 \mathrm{~kg} / \mathrm{t}$.

Keywords: waste paper, testliner, binder, flocculants, fixing, polycationic polymers, electrokinetic properties

\section{References}

1. Ivanov S.I. Tekhnologiia bumagi. [Paper technology]. Moscow, 2006, 696 p. (in Russ.).

2. Kozhevnikov S.Iu., Vdovina O.S., Koverninskii I.N. Tselliuloza. Bumaga. Karton, 2015, no. 5, pp. 64-66. (in Russ.).

3. Shabiev R.O., Smolin A.S., Koverninskii I.N., Kozhevnikov S.Iu. Khimiia rastitel'nogo syr'ia, 2014, no. 4, pp. $263-270$. (in Russ.).

Received January 20, 2016

Revised February 25, 2016 